\title{
The Impact of Policy: How Scientific Publication Policy and Socio- Economics Status Affect Motivation and Types of Publication Among Graduate Students
}

\author{
Rochman Hadi Mustofa ${ }^{1}$, Asri Laksmi Riani ${ }^{2}$, Dewi Kusuma Wardani ${ }^{3}$
}

\begin{tabular}{ll} 
ARTICLE & INFO \\
\hline Article & History: \\
Received 03.10 .2018 \\
Received in revised \\
form 13.12 .2018 \\
Available online 01.04 .2019
\end{tabular}

Scientific publication has become a productivity standard in the academic w orld, especially research. More and more research is expected to result in more scientific publications. Country like Indonesia, which have a very large population, are expected to have a large output of scientific publications. However, based on the data on the number of publications released by Scopus in ASEAN countries, the number of Indonesian publications is still below Malaysia and Singapore (ScimagoJR, 2017), which have fewer populations. Many factors have led to this, such as barriers to technological mastery, lack of time to write (Duracinsky et al. 2017), foreign language mastery (Hazen 2016), economic factors, and legal framework, academic reward system, marketing and ciritical mass (Bjork 2013). To overcome this, the government made a series of policies aimed at increasing interests, motivations and the number of scientific publications, one of which is the Regulation of the Republic of Indonesia, Minister of Research Technology and Higher Education, known as Ristekdikti, no. 44 of 2015 which regulates the obligations of scientific publications for students and lecturers. The policy has had an impact on increasing scientific publications in the last 2 years in Indonesia both at national and international levels. Scientific publication will improve students experience in research and writing. As for teachers, research will lead them to innovation that contributes to school effectiveness (Rahayu et al. 2018). How ever, with many predatory journals, the government anticipates by determining the criteria of a credible journal as the standardized scientific publication. The types of scientific publications used by the students in Indonesia currently refer to the 2017 Ristekdikti Scientific Publication Guidelines which include national journals, accredited journals, international journals, and reputable international journals (Lukman et al. 2017). There are various perceptions that arise from the students with the existence of various scientific publication policies. Many respond positively and negatively. In general, perception is measured based on three aspects, namely cognitive, affective, and conative (Rachmat 2004) (Walgito 2010). Perception, past behavior, self-efficacy, and intention is closely related to the behaviour that will be

${ }^{1}$ Corresponding e-mail: rochmanhm@gmail.com, orcid.org/0000-0001-7903-4948

2; orcid.org/0000-0001-9812-6493

3; orcid.org/0000-0001-5274-1204

Sebelas Maret University ${ }^{1,2,3}$,
Keywords:

\begin{abstract}
Scientific publication policies have been implemented as an effort to increase the level of scientific of scientific publications, especially international publications. Through policies made by the that there will be an increase in scientific publications, especially at the international level. The policy wut not all are at the international level. The author a nalysed the effect of the scientific publication scientific publications, as the endogenous variable. Motivation are used as the mediator between policy has significant and positive effect on the motivation, but insignificant on types of
\end{abstract} Perception, scientific publication policy, socio-economic status, types of publication, motivation. 
carried out by individuals(Ajzen, Czasch \& Flood 2009) (Rhodes \& Courneya 2003) (Zhang 2018). In some studies, the student's perception relates to the quality of education he receives (Akareem \& Hossain 2014).

That, however, affects the student's motivation in making articles for publication. Lack of experience or performance gap (Garside et al. 2015) in scientific publications becomes one of the obstacles that must be overcome while w riting quality scientific publications as the obligation during the study. Lecturers and researchers who have a high teaching load will usually invite master and doctoral students to collaborate in research (Bentley 2011), which can encourage students' motivation to publish. Feedback provided by the lecturers can improve the progress and quality of the students' writing publications (Parr and Timperley 2010). Motivation has a strong relationship to research output, in this case scientific publications (Akinyokum and Uzoka 2007).

Academic environments that support the atmosphere of scientific publications usually have an impact on the students' productivity in making articles for scientific publications (Bland et al. 2002). Providing the facilities such as wi-fi, a complete library (Hadjinicola \& Soteriou 2005), the formation of research groups (Huang et al. 2015), foreign language training, and scientific writing training (Kulage and Larson 2015) is a form of positive academic environmental support. As for the institution, they need to maintain college quality process intact (Almudara 2018). A work environment with an equivalent or higher educational background will arouse the interest, set standards and stimulate someone to write (Kopelman, Brief and Guzzo 1990). They can also communicate and exchange ideas, competencies, resources, share research assignments and find shared results (Ynalvez \& Shrum 2010), and obtain feedback from fellow students (O'Brien et al. 2016). The ability to conduct research and publish it widely is part of a meaningful experience that shows information competency. It is a key metasubject competency consisting of the cognitive, motivational, and activity-based components that generates his own meanings and enriching the subject experience (Tabachuk et al. 2018).

\section{Literature Review and Hypothesis Development}

Perception has many definitions. According to Walgito (2010), perception is a process that starts from the capturing of the five senses to the nervous system so that it creates a form of perception. Perception is influenced by two factors, namely internal and external factors (Toha 2003) and involves three aspects: perceived objects, sensory tools and focus (Walgito 2010). In the context of the scientific publication policy, it is an external factor. In the planned behaviour theory (Ajzen et al. 2009), perception is related to the behaviour that will be committed by the individual and has a strong effect on the decision taken. Meanwhile, the scientific publication policy is a policy designed by the government to increase the number and quality of scientific publications, both nationally and internationally (Lukman et al. 2017).

There are many opinions about the indicators used to measure socio-economic status. Socioeconomic status generally describes a person's existence, health, welfare, surrounding environment, income, educational attainment, prestige, social, household items, cultural, and political participations (Pollack et al. 2007) (Psaki et al. 2014) (Schulz 2005). Meanwhile, motivation is a set of processes that generates, directs and maintains human attitudes in achieving goals (Greenberg \& Baron 2008). It explains the direction, intensity, and perseverance of individuals (Mitchell 1997). A person will be motivated to achieve his goals due to intrinsic and extrinsic motivation (Sardim an 2001). Maslow (1954) explained that motivation is based on five hierarchies, namely physiological needs, safety and security needs, social needs, esteem needs, and self-actualization needs. On one hand, McClelland (1976) explained three things, namely need for achievement, need for affiliation, and need for power.

The hypotheses in this study are as follows:

Hypothesis 1 (H1). The perception of the scientific publication policy has a positive effect on the types of publications. 
Hypothesis 2 (H2). The perception of the scientific publication policy has a positive effect on the motivation.

Hypothesis 3 (H3). The perception of the scientific publication policy has a positive effect on the types of publications with motivation as the mediator.

Hypothesis 4 (H4). Socio-economic status has a positive effect on the types of publications.

Hypothesis 5 (H5). Socio-economic status has a positive effect on the motivation.

Hypothesis 6 (H6). Socio-economic status has a positive effect on the types of publications with motivation as the mediator.

Hypothesis 7 (H7). Students' motivations have positive effects on the types of publications.

\section{Method}

1.1 Questionnaire Development

The questionnaire was developed based on the results of the previous studies and other reliable sources. Each variable has a number of indicators that represent and are develop into statement items measured using a Likert scale of scale 1 (strongly disagree) to 4 (strongly agree). Validity and reliability tests were carried out on the statement items with 35 respondents, which fulfils the minimum requirement of validity and reliability tests of $\geq 30$ (Haryono 2017). Next, a questionnaire was used to collect the data from the sample. The questionnaire contains 37 statement items developed from the following adaptations.

Table 1. Questionnaire Development

\begin{tabular}{|c|c|c|}
\hline Variables & Indicators & Adaptation \\
\hline $\begin{array}{l}\text { Perceptions of } \\
\text { Scientific Publication } \\
\text { Policy (X1) }\end{array}$ & $\begin{array}{ll}- & \text { Affective } \\
- & \text { Cognitive } \\
- & \text { Conative } \\
\end{array}$ & $\begin{array}{l}\text { Ajzen et al. (2009), Rakhmat (2004), } \\
\text { Rhodes \& Courneya (2003) }\end{array}$ \\
\hline $\begin{array}{l}\text { Socio-Economic Status } \\
(\mathrm{X} 2)\end{array}$ & $\begin{array}{l}\text { - } \quad \text { Educational Levels } \\
\text { - } \quad \text { Income or earnings } \\
\text { - } \quad \text { Prestige } \\
\text { - } \quad \text { Power \& Authority }\end{array}$ & $\begin{array}{l}\text { Duncan (1961), Hauser and Warren (1996), } \\
\text { Kyvik and Aksnes (2015), Mueller and } \\
\text { Parcel (1981), Quimbo and Sulabo (2013), } \\
\text { Stevens and Featherman (1981), } \\
\text { Sudarsono (1990), Treiman (1977), Psaki et } \\
\text { al. (2014), Castro et al. (2016) }\end{array}$ \\
\hline Motivation (M) & $\begin{array}{ll}\text { - } & \text { Diligence \& } \\
& \text { perseverance } \\
\text { - } & \text { Showing interests } \\
\text { - } & \text { Happiness } \\
\text { - } & \text { Easy to get bored on } \\
& \text { the routine } \\
& \text { assignments } \\
\text { - } & \text { Need for achievement } \\
\text { - } & \text { Need for affiliation } \\
\text { - } & \text { Need for power }\end{array}$ & $\begin{array}{l}\text { McClelland et al. (1976), Pasaribu and } \\
\text { Simanjuntak (1986), Sardiman (2001), } \\
\text { Slameto (1995) }\end{array}$ \\
\hline $\begin{array}{l}\text { Types of Publications } \\
(\mathrm{Y})\end{array}$ & $\begin{array}{ll}\text { - } & \text { National journal or } \\
& \text { proceeding } \\
\text { - International journal } \\
\text { or proceeding }\end{array}$ & Lukman et al. (2017). \\
\hline
\end{tabular}

1.2 Samples

The population were \pm 400 master program students, and 242 students filled out the questionnaires. The questionnaires were made in the form of Google forms sent through social media messages. They were sent to the respondents who met the criteria of having scientific publications, both those with the status of "published, to be published, accepted and in the process 
of reviewing". This criterion was chosen because the students had gone through the consideration phase of choosing journals or proceedings for scientific publications.

Table 2. The Summary of the Respondent Characteristics

\begin{tabular}{llll}
\hline Variables & Description & Frequency & Percentage (\%) \\
\hline Gender & Male & 117 & 51.65 \\
& Female & 125 & 48.35 \\
\hline Semester of Study & 2 & 4 & 1.65 \\
& 3 & 34 & 14.05 \\
& 4 & 105 & 43.39 \\
& 5 & 47 & 19.42 \\
& 6 & 33 & 13.64 \\
& 7 & 19 & 7.85 \\
\hline
\end{tabular}

As shown in Table 2, the first column is the gender of the respondents consisting of 117 men and 125 women. It $w$ as seen that more male respondents were involved in the study by $51.65 \%$ while female respondents were $48.35 \%$. The second column shows the semester level taken by the respondents when the research $w$ as carried out. Some students in the $5^{\text {th }}, 6^{\text {th }}$ and $7^{\text {th }}$ semester have passed the study, but due to the consideration of fulfilling the criterion, namely to publish while they were still active as a student, they could participate in the research.

\section{Data and Result Analyses}

\subsection{Construct Validity}

The indicator validity was assessed from the Loading Factor value or $L F \geq 0.7$ (a strong level of validity) while the LF value of 0.5 - 0.6 could still be accepted and valid (Hair et al. 2017) (Yamin \& Kurniawan 2011) (Fornell \& Larcker 1981). The construct was still acceptable if LF=0.4 (Wijaya \& Mustafa 2013). The construct used in this study was LF 0.5-0.6. After testing the construct validity, the coefficient value that matched the criteria was obtained.

\subsection{Construct Reliability}

The construct reliability was assessed by evaluating the value of Cronbach's Alpha and Composite Reliability. If the value $\geq 0.7$, it is acceptable. if the value $\geq 0.78$, it is very satisfying (Haryono 2017). Meanwhile, the value of Average Variance Extracted was used to explain the convergent validity value (Fornell \& Larcker 1981) (Ghozali 2014). If the $\sqrt{ }$ AVE value is greater than the construct correlation value, it can be interpreted that the requirement of the discriminant validity has been fulfilled.

Table 3. Composite Reliability, Cronbach's Alpha, AVE and $\sqrt{ }$ AVE

\begin{tabular}{lllll}
\hline Construct & $\begin{array}{l}\text { Composite } \\
\text { Reliability }\end{array}$ & $\begin{array}{l}\text { Cronbach's } \\
\text { Alpha }\end{array}$ & AVE & VAVE \\
\hline $\mathrm{X} 1$ & 0.911 & 0.896 & 0.489 & 0.699 \\
\hline $\mathrm{X} 2$ & 0.914 & 0.896 & 0.458 & 0.677 \\
\hline $\mathrm{S}$ & 0.935 & 0.924 & 0.496 & 0.704 \\
\hline $\mathrm{Y}$ & 0.715 & 0.778 & 0.569 & 0.754 \\
\hline
\end{tabular}

Table 4. Latent Variable Correlation

\begin{tabular}{lllll}
\hline Code & $\mathrm{X} 1$ & $\mathrm{X} 2$ & $\mathrm{~S}$ & $\mathrm{Y}$ \\
\hline $\mathrm{X} 1$ & 1.000 & - & - & - \\
\hline $\mathrm{X} 2$ & 0.596 & 1.000 & - & - \\
\hline $\mathrm{S}$ & 0.740 & 0.767 & 1.000 & - \\
\hline $\mathrm{Y}$ & 0.463 & 0.340 & 0.581 & 1.000 \\
\hline
\end{tabular}


Based on Table 3, it can be seen that the value of composite reliability and Cronbach's alpha is 70.7 so that the requirement of the construct reliability is fulfilled. Furthermore, by comparing the $\sqrt{ } \mathrm{AVE}$ value with Table 4, it is known that the square root of AVE is greater than the correlation value between the constructs in the model, so that the requirement of discriminant validity is fulfilled.

4.3 Hypothesis Testing

The testing phase of the hypothesis in PLS was done using Structural Equation Modeling (SEM). The application used was SmartPLS 3.0. After the bootstrapping phase, the T Statistic value in the path coefficients table could determine the effect between the latent variables. If the T Stat value $\geq$ 1.96 or P Value is 0.05 (5\% significance), it has a significant effect. The path coefficient table can be seen as follows.

Table 5. Path Coefficients

\begin{tabular}{llllll}
\hline & $\begin{array}{l}\text { Original } \\
\text { Sample }\end{array}$ & T Table & T Statistic & P Value & Description \\
\hline $\mathrm{X} 1 \rightarrow \mathrm{M}$ & 0.439 & 1.96 & 10.53 & 0.000 & Significant \\
\hline $\mathrm{X} 1 \rightarrow \mathrm{Y}$ & 0.072 & 1.96 & 0.81 & 0.420 & Insignificant \\
\hline $\mathrm{X} 2 \rightarrow \mathrm{M}$ & 0.505 & 1.96 & 11.04 & 0.000 & Significant \\
\hline $\mathrm{X} 2 \rightarrow \mathrm{Y}$ & 0.324 & 1.96 & 2.76 & 0.006 & Significant \\
\hline $\mathrm{M} \rightarrow \mathrm{Y}$ & 0.667 & 1.96 & 5.66 & 0.000 & Significant \\
\hline $\mathrm{X} 1 \rightarrow \mathrm{M} \rightarrow \mathrm{Y}$ & 0.293 & 1.96 & 4.72 & 0.000 & Significant \\
\hline $\mathrm{X} 2 \rightarrow \mathrm{Y}$ & 0.337 & 1.96 & 5.05 & 0.000 & Significant \\
\hline
\end{tabular}

Figure 1. Path Coefficients

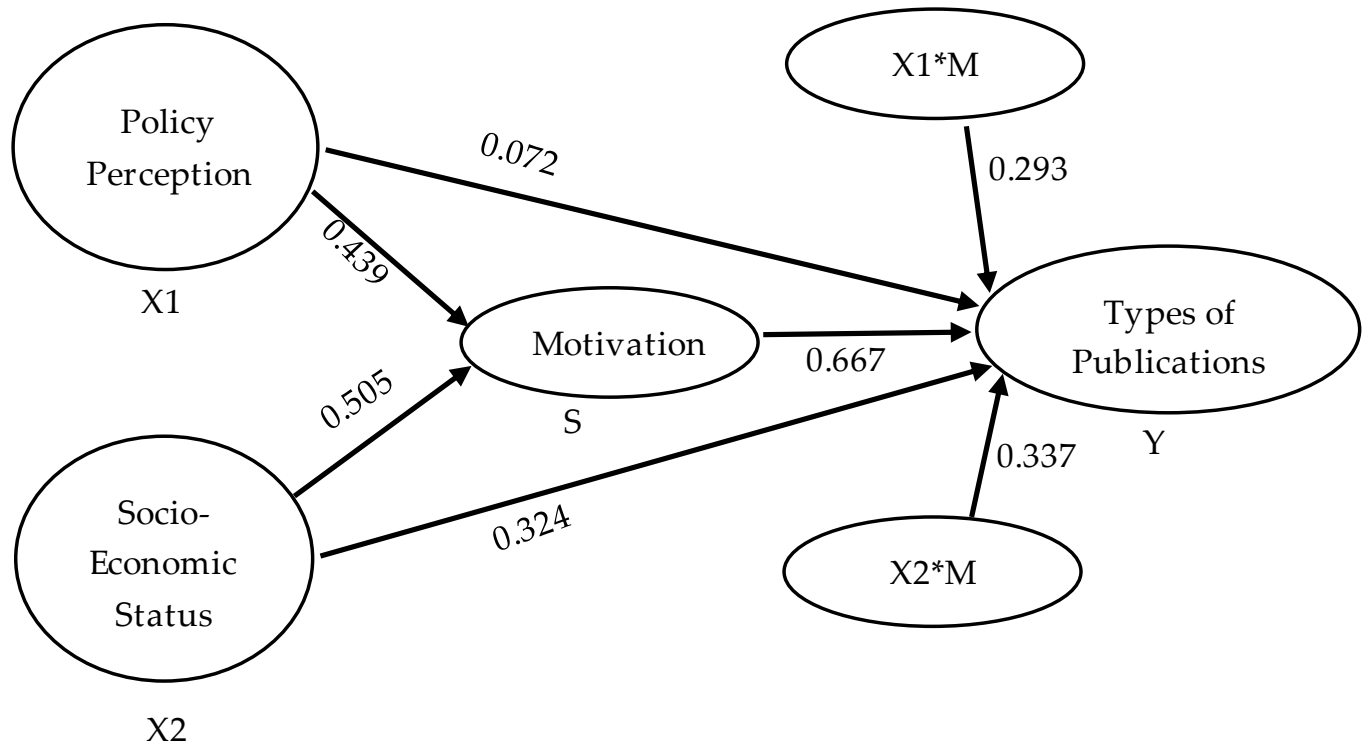

Based on Table 5, we can see the $T$ statistic value of each latent construct relationship. The $T$ Stat value must be $\geq \mathrm{T}$ Table for a significant relationship. From the 7 hypotheses proposed, we can see 6 hypotheses with significant and positive values while 1 hypothesis is not significant.

a. Hypothesis 1 (H1). The perception of the scientific publication policy has a positive and significant effect on the types of publications $(\mathrm{X} 1 \rightarrow \mathrm{Y})$.

$T$ Statistic value is 0.81 smaller than $\mathrm{T}$ Table, and $\mathrm{P}$ Value is 0.420 greater than the significance of 0.05 (T Stat $\leq \mathrm{T}$ Table) (P Value $\geq 0.05$ ). This value show s that the scientific publication policy perception (X1) does not affect the types of publications $(\mathrm{Y})$. The original value of the interaction is also very low at 0.072 , meaning that the effect arising from the relationship is only $7.2 \%$. Based on these results, hy pothesis 1 (H1) is rejected. 
b. Hypothesis 2 (H2). The perception of the scientific publication policy has a positive and significant effect on the motivation $(\mathrm{X} 1 \rightarrow \mathrm{M})$.

$T$ Statistics value is 10.53 more than T Table, and P Value is 0,000 smaller than the significance of 0.05 (T Stat $\geq \mathrm{T}$ Table) (P Value $\leq 0.05$ ). This value shows that the perception of the scientific publication policy (X1) influences the motivation (M). The original value in this relationship is 0.439 , meaning that the effect that appears is as big as the perception of the scientific publication policy that is $43.9 \%$ of motivation. Thus, hypothesis 2 (H2) is accepted.

c. Hypothesis $3(\mathrm{H} 3)$. The perception of the scientific publication policy has a positive and significant effect on the types of publications with motivation as the mediator $(X 1 \rightarrow M \rightarrow Y)$.

Hypothesis 3 illustrates the relationship that uses a mediator. The T Statistic value is 4.72 greater than T Table, and P value is smaller than the significance of 0.05 ( T Stat $\geq T$ Table) (P Value $\leq$ 0.05). Based on this, it can be said that the perception of the scientific publication policy has a significant effect on the types of publications when motivation is the mediator. This result is different from hypothesis 1 (H1) which illustrates the absence of very low effect or the effect on the types of publications selected. This makes sense because perception will cause motivation before the action arises. The amount of effect in $\mathrm{H} 3$ corresponds to the original value of 0.293 or $29.3 \%$. Therefore, the conclusion of hypothesis $3(\mathbf{H} 3)$ is accepted.

d. Hypothesis 4 (H4). Socio-economic status has a positive and significant effect on the types of publications $(\mathrm{X} 2 \rightarrow \mathrm{Y})$

The $T$ Statistic value at $\mathrm{H} 4$ is 2.76 greater than $\mathrm{T}$ Table, and $\mathrm{P}$ value is smaller than the significance of 0.05 (T Stat $\geq \mathrm{T}$ Table) (P Value $\leq 0.05$ ). Based on these values, socio-economic status has a significant effect on the types of publications. The amount of effect in accordance with the original value is 0.324 or $32.4 \%$. Based on these data, hypothesis 4 (H4) is accepted.

e. Hypothesis 5 (H5). Socio-economic status has a positive and significant effect on the motivation $((\mathrm{X} 2 \rightarrow \mathrm{M})$.

The T Statistic value at H5 is 11.04, and P value is 0.00 ( $T$ Stat $\geq \mathrm{T}$ Table) (P Value 5 0.05). Based on these data, socio-economic status has a significant effect on motivation. The amount of effect is in accordance with the original value of 0.505 or $50.5 \%$. Thus, it can be concluded that hypothesis 5 (H5) is accepted.

f. Hypothesis 6 (H6). Socio-economic status has a positive and significant effect on the types of publications with motivation as the mediator $(\mathrm{X} 2 \rightarrow \mathrm{M} \rightarrow \mathrm{Y})$.

The T Statistic value at $\mathrm{H} 6$ is 5.05 or greater than the T Table, and P Value of 0.00 (T Stat $\geq \mathrm{T}$ Table) (P Value $\leq 0.05$ ). Based on these data, it can be said that socio-economic status has a significant effect on the types of publications with motivation as the mediating variable. The amount of effect according to the original value is 0.337 or $33.7 \%$. Based on these data, hypothesis 6 (H6) is accepted.

g. Hypothesis 7 (H7). Students' motivations have positive and significant effects on the types of publications $(\mathrm{M} \rightarrow \mathrm{Y})$.

T Statistic value at $\mathrm{H} 7$ is 5.66 or greater than T Table, and P Value of 0.00 (T Stat $\geq \mathrm{T}$ Table) (P Value 0.05). Based on these values, it can be said that the students' motivations have significant effects on the types of publications. The amount of effect according to the original value is 0.667 or $66.7 \%$. Based on these data, the hy pothesis 7 (H7) is accepted.

\section{Discussion, Implication, and Limitation}

\subsection{Discussion}

Based on the results of the analysis, the author obtained a picture that the policy carried out by the government will have an impact on increasing the quantity of scientific publications. Besides that, there are many other factors involved and determining. Using SEM analy sis makes it easier for the author to see the effect and relationship of each variable that forms the construct or indicator. The students' perceptions of the scientific publication policy made by the government, for example in the planned behaviour theory (Ajzen et al. 2009), are closely related to the behaviour that will be carried out. When the government makes a policy that is directly related to the students, it becomes a 
stimulus. They will perceive whether the policy is beneficial or not for them. Then, they will try to measure their ability, explore the information needed to, and then react.

However, when perception is associated with individual motivation, it can be a stronger stimulus. Many previous studies have linked perceptions with motivations and behaviours (Postman 1953). Chen \& Hoshower's research (2010) shows that the students who have the motivation to be involved in the learning process can significantly affect their expectations about meaningful learning. This is consistent with the research of Ames \& Archer (1988) stating that students with positiveinitial perceptions of learning will be more motivated to achieve goals and have more positive attitudes during learning. This explains why the relationship in hypotheses 1 and hypothesis 3 has different results even though both have the same endogenous and exogenous variables. Hypothesis 1 can be said to have no significant effect or have a very low effect on the types of scientific publications chosen. On other hand, in hypothesis 3, through motivation as the mediator, the effect of perception becomes significant and positive. In this analysis, motivation has an important role in the construct, as in Basset's study (Basset et al. 2015) which stated that lack of the student motivation will have an impact on the learning evaluation results. Referring to the research hypothesis, it is known that motivation has the greatest effect on the types of publications (Akinyokum \& Uzoka 2007) (Bailey 1999). Some research supports this opinion. Policies that are made without generating enough motivation for the students will have little effect. Publication policies that can motivate students are usually those related to career paths and progression (Griffin \& Hindocha 2011), supporting their scientific clusters (Hangel \& Schmidt-Pfister 2017), or the existence of rewards. On the other hand, motivation for publications that arises from within is usually related to feeling satisfied when conducting scientific publications (Wulandari \& Utomo, 2013), pleasure in the learning process (Clark et al. 2014), and the feeling of publication importance (Griffin \& Hindocha 2011).

Based on hypothesis 4, socioeconomic status has a positive effect on the types of publication. This supports the opinion that socioeconomic factors are the fundamental aspects of learning achievement (Castro, Ortiz \& Lemus 2016). We can say that scientific publications are a certain achievement in learning. Some findings indicate that the students' reasons for socioeconomic publications are self-esteem (Widodo \& Pratitis 2013), self-actualization (Ginting 2013), professional occupation awareness (Byard 2013), prestige (Srinivasan et a. 2014), fulfilment and selfempowerment (Maoto 2011). As graduate students, scientific publications gives them more confidence and help them prepare for careers as researchers. It was also found that socio-economic status has an effect on the motivation based on the hypothesis 5. Similar to Li (Li \& Stone, 2018) which found that the students' social environment affects their academic motivations. The students in these research academicians, and the people with equal or higher education tend to be more motivated to conduct research and publications (Zhang, 2014). Funding sources are also an important factor in the socio-economic status. The high cost of the Article Processing Charge (APC) is still a barrier for the students to publish scientific articles (Solomon \& Bjork 2012). This is inseparable from their limited financial ability. The advantages of the socio-economic status can influence the achievement motivation and have an impact on the academic achievement (Schultz 1993), in this case the scientific publications. This socio-economic aspect is in accordance with the results of this study that the socio-economic status influences the types of the students' scientific publications, both directly and indirectly through motivation as the mediator.

Hypothesis 7 states that motivation has a positive and significant effect on the types of publication. This is in line with the previous research such as the desire to provide benefits and social influences (Järvelä, Volet \& Järvenoja 2010), self-efficacy (Bailey 1999), and other extrinsic factors such as remuneration (Mahagaonkar 2010), supports for academic facilities, and career considerations (Diamantes 2004). For a long time, it has been realized that intrinsic and extrinsic factors have significant effects on the research productivity (Cerasoli, Nicklin \& Ford 2014). Other research also shows that the desire to disseminate research findings and share to other researchers (Zain et al. 2011) is the reason why they publish.

5.2 Conclusion 
Policies made by the government and universities that aim to improve the quality and quantity of research are indeed positive things. Policies that accommodate interests and encourage motivation are required. This is in as much as the policies that focus on the results and put aside the conditions of the students, preparedness, interest, or socio-economic, will have an impact on increasing pressure. If the government really $w$ ants to maximize the potential of an abundant number of academia, it is also necessary to build a conducive learning environment and be able to increase the student awareness for research and publication. In some developed countries, the high level of publication is more due to the awareness of academia to disseminate knowledge, the existence of funding support from institutions, and the establishment of a good learning climate. When the students' motivations and interests for research are well established, they will naturally conduct research on an ongoing basis.

5.3 Implication

Based on the results above, the following implications can be generalized:

First, the scientific publication policy, according to data released in various media, has indeed shown an increase, but in this study it was found that the policy did not directly affect the types of publications. The new publication policy has a significant effect when motivation acts as a mediator. This is natural because many studies show that motivation does have a profound effect on one's decision. Therefore, it can be summed up that a policy must be enough to inspire someone's motivation so that he is willing to implement it. The government needs to provide sufficiently favourable regulations for the students such as funding support for certain research, aw arding the students with quality research, and focusing on national research. Hence, this policy provides motivation and fosters the interest in conducting research and publications. The government needs to understand that the policies made are not always effective in encouraging the students. On the contrary, motivation and self-aw areness from the students are needed.

Second, the socio-economic status has a significant effect on the types of publications, both directly and through the motivation as the mediator. These results are also supported by several other studies discussed earlier. This is inseparable from factors such as the environment around the individual that affects, as well as the number of types of journals available. Some offer free open access and low APC which greatly help students with limited financial conditions. Some others offer rapid review processes, but charge high costs, and so on. This is what led to the consideration of the students in choosing various types of scientific publications. The things that the students expect from a scientific publication include the rapid review process, affordable fees, and good reputation.

Third, motivation is good mediator. This is inseparable from the role of motivation as an individual driver to act. There are a lot of studies that describe motivation as a variable that affects other variables and vice versa. Hence, it is not surprising if motivation gives a significant effect on the other variables in this study. It should be noted that policies that influence motivation are more likely to succeed.

5.3 Limitation

Although this study brings findings and implications, it is important to realize that this research has its limitations. This scientific publication policy only focuses on the policy in one place because the research sample is taken in a limited way. It needs to be tested in other studies with different conditions and cultures in order to obtain broader generalizations. In addition, the indicators used for the research are limited, such as the indicators for measuring overall socioeconomic status. However, authors decided to focus on the aspects that are still related to the sample profile. In the future, it can be adjusted to the needs if you want to use the socio-economic status variable. The authors hopes that the findings in this study are useful for other relevant research, and is open to receive input for more comprehensive research purposes.

\section{Acknowledgement}

The author would like to thank to all respondents who are giving their time to be interviewed and supervisor for feedback on this research. The authors thank to the editor and reviewers for their thoughtful comments and suggestions on the paper. 
Mustofa,R.H., Riani,A.L. \& Wardani,D.K. (2019).The Impact of Policy: How Scientific Publication Policy and Socio-Economics Status Affect Motivation and Types of Publication Among Graduate Students.International Journal of Educational Research Review,4(2),121-132.

\section{Conflict of Interest}

The authors declare no conflict of interest in this research.

\section{References}

Ajzen, I., Czasch, C. \& Flood, M. G. (2009). From intentions to behavior: implementation intention, commitment, and conscietiousness. Journal of Applied Social Psychology, 39(6), pp. 1356-1372.

Akareem, H.S. \& Hossain, S. S. (2014). Determinants of education quality: what makes students' perception different. Open Review of Educational Reseacrh, 3(1), pp. 52-67.

Akinyokum, O.C. \& Uzoka, F.M.E. (2007). Factor analysis of the effects of academic staff profile on the investment portofolio of a university. International Journal of the Computer, the Internet and Management, 15 , pp. $51-62$.

Almudara, S.B. (2018). Total quality management to reduce cost and to improve quality process in education institution. International Journal of Educational Research Review, 3(2), pp. 22-28.

Ames, C. \& Archer, J. (1988). Achievement goals in the classroom: students' learning strategies and motivation processes. Journal of Educational Psychology, 80(3), pp. 260-267.

Bailey, J.G. (1999). Academics motivation and self-efficacy for teaching and research. Higher Education Reseacrh \& Development, 183(3), pp. 343-359.

Bassett, J., Cleveland, A., Acorn, D., Nix, M., \& Snyder, T. (2015). Are they paying attention? Students' lack of motivation and attention potentially threaten the utility of course evaluation. Assessment $\mathcal{E}$ Evaluation in Higher Education, 42(3), pp. 431-442.

Bentley, Peter. (2011). Gender Differences and Factors Affecting Publication Productivity Among Australian University Academics. Journal of Sociology, 48 (1), pp. 85 - 103.

Bjork, B.C. (2013). Open access-are the barriers to change receding?. Publications, 1, pp. 5-15

Bland, C., J., Seaquist, J. E., Pacala, J. T., Center, B., \& Finstad, D. (2002). One school's strategy to assess and improve the vitality of its faculty. Academic Medicine, 77 (5), pp. $368-376$.

Byard, R.W. (2013). Scientific writing: the process and the pitfalls. Forensic Science, Medicine, and Pathology, 9(3), pp. 285-286.

Castro, L.M.C., Ortiz, F. \& Lemus, D.F. (2016). Construction of a family socioeconomic index for the students who present the Saber 11 test. Statistics on the Evaluation of Education, 9(1), pp. 73-84.

Cerasoli, C.P., Nicklin, J.M. \& Ford, M.T. (2014). Intrinsic motivation and extrinsic incentives jointly predict performance: a 40-year meta analysis. Psychological Bulletin, 140(4), pp. 980-1008.

Chen, Y. \& Hoshower, L. (2010). Student evaluation of teaching effectiveness: an assesment of student perception and motivation. Assessment $\mathcal{E}$ Evaluation in Higher Education, 28(1), pp.71-88.

Clark, M.H., Middleton, S. C., Nguyen, D. \& Zwick, L. K. (2014). Mediating relationships between academic motivation, academic integration and academic performance. Learning and Individual Differences, 33, pp. 30-38.

Diamantes, T. (2004). What principals think motivate teachers. Journal of Instructional Psychology, 31(1), pp. 68-70.

Driscoll, J. \& Driscoll, A. (2002).Writing an Article for Publication: an Open Invitation. Journal of Orthopaedic Nursing, 30 (4), pp. $144-152$.

Duncan, O. D. (1961). A socioeconomic index for all occupations. New York: Free Press.

Duracinsky, M., Lalanne, C., Rous, L., Dara, A.F., Baudoin, L., Pellet, C., Deschamps, A., Peretz, F. \& Chassany, O. (2017). Barriers to publishing in biomedical journals perceived by a sample French researchers: results of the DIAzePAM study. BMC Medical Research Methodology, 17(1), 96.

Fornell, C. \& Larcker, D. F. (1981). Evaluating structural equation models with unobservable variable and measurement error. Journal of Marketing Research, 18, pp. 39-50.

Garside, J., Bailey, R., Tyas, M., Ormrod, G., Stone, G., Topping, A. \& Gillibrand, W. P. (2015). Developing a culture of publication: a joint enterprise w riting retreat. Journal of Applied Research in Higher Education, 7 (2), pp. 429 - 442. 
Mustofa,R.H., Riani,A.L. \& Wardani,D.K. (2019).The Impact of Policy: How Scientific Publication Policy and Socio-Economics Status Affect Motivation and Types of Publication Among Graduate Students.International Journal of Educational Research Review,4(2),121-132..

Ghozali, I. (2014). Structural equation modeling metode alternatif dengan partial least square (PLS). Semarang: Badan Penerbit Universitas Diponegoro. ISBN 979-704-300-2.

Ginting, D.A. (2013). Faktor-faktor yang mempengaruhi minat mahasiswa akuntansi dalam menulis dan mempublikasikan karya ilmiah (studi kasus pada tiga perguruan tinggi negeri di kota Malang). Jurnal Ilmiah Mahasiswa FEB (Online), 2(1).

Greenberg, J. \& Baron, R. A. (2008). Behavior in Organizations (Ninth Edition). Singapore: Prentice Hall International.

Griffin, M.F. \& Hindocha, S. (2011). Publication practices of medical students at british medcal schools: experience, attitudes and barriers to publish. Medical Teacher, 33(1), pp. e1-e8.

Hadjinicola, G. C. \& Soteriu, A. C. (2005). Factors affecting research productivity of production and operations management groups: an empirical study. Journal of Applied Mathematics and Decision Sciences, vol2006, pp. $1-16$.

Hair, J. F., Hult, G. T. M., Ringle, C. M. \& Sarstedt, M. (2017). A Primer on partial least squares strutural equation modeling (PLS-SEM), Second Edition. California: SAGE Publications, Inc.

Hangel, N. \& Schmidt-Pfister, D. (2017). Why do you publish? On the tension between generating scientific knowledge and publication pressure. Journal of Information Management, 69(5), pp. 529544.

Haryono, Siswoyo. (2017). Metode SEM untuk Penelitian dengan AMOS 22.00, LISREL 8.80 dan SMARTPLS 3.0. Jakarta Timur: Luxima Metro Media, pp. 5-113. ISBN 978-602-268-176-2.

Hauser, R. M. \& Warren, J. R. (1996). Socioeconomic indexes for occupations: a review, update, and critique. Center for Demography and Ecology, 96 (1).

Hazen, Benjamin T. (2016). Overcoming basic barriers to publishing research. The International Journal of Logistics Management, 27(1).

Huang, G., Fang, C. H., Lopez, S. A., Bhagat, N., Langer, P. D. \& Eloy, J. A. (2015). Impact of fellowship training on research productivity in academic ophthalmology. Journal of Surgical Education, 72 (3), pp. $410-417$.

Järvelä, S., Volet, S. \& Järvenoja, H. (2010). Research on motivation in collaborative learning: moving beyond the cognitive-situative divide and combining individual and social processes. Educational Psychologist, 45(1), pp. 15-27.

Kopelman, R. E., Brief, A. \& Guzzo, R. A. (1990). The role of climate and culture in productivity. Organizational Climate and Culture, pp. $282-318$.

Kulage, K. M. \& Larson, E. L. (2015). Implementation and outcomes of a faculty-based, peer review manuscript w riting w orkshop. Journal of Professional Nursing, 0 (0) February 2016, pp. 1 - 9.

Kyvik, S. \& Aksnes, D.W. (2015). Explaining The Increase in Publication Productivity among Academic Staff: a Generational Perspective. Studies in Higher Education, 40 (8), pp. 1438 - 1453.

Li, M. \& Stone, H. N. (2018). A social networks analysisis of the impact of a teacher and student community on academic motivation in science classroom. Societies, 8(3), pp. 68.

Lukman, Ahmadi, S. S., Manalu, W. \& Hidayat, D. S. (2017). Pedoman Publikasi Ilmiah. Jakarta: Direktorat Jenderal Penguatan Riset dan Pengembangan.

Lukman, Yaniasih, Maryati, I., Silalahi, M.A. \& Sihombing, A. (2016). Kekuatan 50 Institusi Ilmiah Indonesia: Profil Publikasi Ilmiah Terindeks Scopus. Jakarta: Kementrian Riset Teknologi dan Pendidikan Tinggi.

Mahagaonkar, P. (2010). Money and ideas: four studies on finance, innovation and the business life cycle. International Studies in Entrepreneurship, 25, pp. 37-54.

Maoto, S. (2011). Making sense of undergraduate students' reflections as they learn through writing an action research proposal. South African Journal of Higher Education, 25(8), pp. 1563-1580.

Maslow, Abraham. (1954). Motivation and personality. New York: Harper \& Row.

McClelland, D. C. (1976). Human motivation. Cambridge: CUP Archive.

Mitchell, T. R. (1997). Research in organizational behavior. Greenwich: JAI Press.

Mueller, C. W. \& Parcel, T. (1981). Measures of socioeconomic status: alternatives and recommendations. Child Development, $52(1)$, pp. $13-30$ 
Mustofa,R.H., Riani,A.L. \& Wardani,D.K. (2019).The Impact of Policy: How Scientific Publication Policy and Socio-Economics Status Affect Motivation and Types of Publication Among Graduate Students.International Journal of Educational Research Review,4(2),121-132.

O'Brien, S. P., Marken, D.; \& Petrey, K. B. (2016). Student perceptions of scholarly w riting. The Open Journal of Occupational Therapy: 4(3), Article 8, pp.1-17.

Parr, J. M., \& Timperley, H.S. (2010). Feedback to writing, assessment for teaching and learning and student progress. Assessing Writing, 15(2), pp. 68-85.

Pasaribu, I.L. \& B. Simanjuntak. (1986). Sosiologi Pembangunan. Bandung: Tarsito

Pollack, C.E., Chideya, S., Cubbin, C., Williams, B., Dekker, M. \& Braveman, P. (2007). Should health studies measure wealth? A systematic review. American Journal of Preventive Medicine, 33(3), pp. 250-264.

Postman, Leo. (1953). Perception, motivation and behavior. Journal of Personality, 22(1), pp. 17-31.

Psaki, S.R., Seidman, J.C., Miller, M., Gottlieb, M., Bhutta, Z.A., Ahmed, T., Ahmed, A.M.S., Bessong, P., John, S.M., Kang, G., Kosek, M., Lima, A., Shrestha, P., Svensen, E. \& Checkley, W. (2014). Measuring socioeconomic status in multicountry studies: Results from the eight-country MALED study. Population Health Metrics, 12(8)

Quimbo, M. A. T. \& Sulabo, E. C. (2013). Research productivity and its policy implications in higher education institutions. Studies in Higher Education, 39 (10), pp. 1955 - 1971.

Rahayu, S., Ulfatin, N., Wiyono, B. B., Imron, A. \& Wajdi, M. B. N. (2018). The professional competency teachers mediate the influence of teacher innovation and emotional intelligence on school security. Journal of Social Studies Education Reseaech, 9(2), pp. 210-227.

Rakhmat, Jalaluddin. (1996). Psikologi Komunikasi. Jakarta: Remaja Rosdakarya, pp. 37-43. First published 1985. ISBN 979-514-145-7.

Rhodes, R.E. \& Courneya, K.S. (2003). Investigating multiple components pf attitude, subjective norm, and perceived control: an examination of the theory of planned behavior in the exercise domain. British Journal of Psychology, 42(4), pp. 129-146.

Sardiman, A.M. (2001). Interaksi dan motivasi belajar mengajar. Jakarta: Raja Grafindo Persada.

Schultz, Geoffrey F. (1993). Socioeconomic advantage and achievement motivation: important mediators of academic performance in minority children in urban schools. The Urban Review, 25(3), pp. 221-232.

Schulz, Wolfram. (2005). Measuring the socio-economic background of students and its effect on achievement in PISA 2000 and PISA 2003. Annual Meetings of the American Educational Research Association. San Francisco.

Scimagojr. (2017). Scimago journal and country rank on asean country. retrieved from http://scimagojr.com/countryrank.php.

Slameto. (1995). Belajar dan Faktor-Faktor yang Mempengaruhi. Jakarta: PT Rineka Cipta.

Solomon, D. J. \& Bjork, B. C. 2012. Publication fees in open access publishing: sources of funding and factors influencing choice of journal. Journal of the American Science and Technology, 63(1), pp. 98107.

Srinivasan, M.R., Poorni, S., Sujatha, G. \& Kumar, S.N. (2014). Research experiences, attitudes, and barriers to publishing among the dental postgraduate teachers: a cross-sectional study. Indian Journal of Dental Research, 25(4), pp.454-458.

Stevens, G. \& Featherman, D.L. (1981). A revised socioeconomic index of occupational status. Social Science Research, 10 (4), pp. $364-395$.

Sudarsono, FX. (1990). Pengukuran status sosial ekonomi dan permasalahannya. Populasi, 2 (1), pp. 21 -27 .

Tabachuk, N. P., Ledovskikh, I. A., Shulika, N. A., Karpova, I. V., Kazinets, V. A. \& Polichka, A. E. (2018). Information competency and creative initiative of personality and their manifestation in activity. Journal of Social Studies Education Research, 9(1), pp. 168-186.

Toha, Mohtar. (2003). Perilaku Organisasi (Konsep Dasar dan Aplikasinya). Jakarta: Grafindo Persada. Treiman, Donald J. (1977). Occupational prestige in comparative perspective. New York: Academic Press. Walgito, Bimo. (2010). Pengantar Psikologi Umum. Yogyakarta: ANDI Yogyakarta. ISBN 978-979-291455-9. 
Widodo, A.S. \& Pratitis, N.T. (2013). Harga diri dan interaksi sosial ditinjau daristatus sosial ekonomi orang tua. Persona: Jurnal Psikologi Indonesia, 2(2), pp. 131-138.

Wulandari, T. \& Utomo, A. S. (2013). Motivasi pustakaw an dalam menulis karya ilmiah pada terbitan berkala di badan arsip dan perpustakaan jaw a tengah. Jurnal Ilmu Perpustakaan, 2(4).

Yamin, S. \& Kurniawan, H. (2011). Generasi Baru Mengolah Data Penelitian dengan Partial Least Square Path Modeling. Jakarta: Salemba Empat

Ynalvez, M. A. \& Shrum, W. M. (2010). Professional networks, scientific collaboration, and publication productivity in resource-constrained research institutions in a developing country. Research Policy, 40 (2011), pp. $204-216$.

Zain, S., Ab-Rahman, M.S., Ihsan, A.K.A.M, Zahrim, A., Nor, M.J.M., Zain, M.F.M., Hipni, A., Ramli, N.L. \& Ghopa, W.A.W. (2011). Motivation for research and publication: experience as a researcher and an academic. Procedia - Social and Behavioral Science, 18, pp. 213-219.

Zhang, Ke. (2018). Theory of planned behavior: origins, development and future direction. International Journal of Humanities and Social Science Invention, 7(5), pp. 76-83.

Zhang, Xhinyan. (2014). Factors that motivate academic staff to conduct research and influence research productivity in Chinese project 211 universities. Thesis Doctorate in Business Administration ata University of Canberra, Australia 